\title{
Protein Kinase C Disrupts Cannabinoid Actions by Phosphorylation of the CB1 Cannabinoid Receptor
}

\author{
D. E. Garcia, ${ }^{1,3}$ S. Brown, ${ }^{2}$ B. Hille, ${ }^{1}$ and K. Mackie ${ }^{1,2}$ \\ Departments of ${ }^{1}$ Physiology and Biophysics and ${ }^{2}$ Anesthesiology, University of Washington, Seattle, Washington 98195 , \\ and ${ }^{3}$ Departamento de Fisiologia, Facultad de Medicina, Universidad Nacional Autonoma de Mexico, CP 04510 Mexico \\ DF, Mexico
}

\begin{abstract}
We have found that phosphorylation of a G-protein-coupled receptor by protein kinase $\mathrm{C}$ (PKC) disrupts modulation of ion channels by the receptor. In AtT-20 cells transfected with rat cannabinoid receptor (CB1), the activation of an inwardly rectifying potassium current $\left(\mathrm{K}_{\mathrm{ir}}\right.$ current) and depression of P/Qtype calcium channels by cannabinoids were prevented by stimulation of protein kinase $C$ by 100 nm phorbol 12-myristate 13-acetate (PMA). In contrast, activation of $\mathrm{K}_{\mathrm{ir}}$ current by somatostatin was unaffected, and inhibition of calcium channels was only modestly attenuated. The possibility that PKC acted
\end{abstract}

Neurons are continuously exposed to neuromodulators that bind G-protein-coupled receptors (GPCRs) and alter neuronal excitability (Hille, 1994). Many modulators decrease electrical excitability by activating inwardly rectifying potassium currents $\left(\mathrm{K}_{\mathrm{ir}}\right.$ currents) and inhibiting voltage-dependent calcium currents $\left(I_{\mathrm{Ca}}\right)$, often via pertussis toxin (PTX)-sensitive G-proteins (North, 1989). Other modulators stimulate phospholipase C, generating diacylglycerol and $\mathrm{IP}_{3}$, which increase intracellular calcium levels and activate protein kinase $\mathrm{C}$ (PKC) (Huang and Huang, 1993). Activation of PKC often enhances neurotransmission (Malenka et al., 1986; Capogna et al., 1995). The mechanism and the interaction and balance between neuronal stimulation and inhibition by these two classes of receptors can now be studied directly.

Activation of protein kinase $\mathrm{C}$ attenuates the modulation of $\mathrm{N}$ and P/Q-type calcium currents and of $\mathrm{K}_{\mathrm{ir}}$ currents by G-proteincoupled receptors. For all three channels, the fast modulation is mediated by direct binding of G-protein $\beta \gamma$ subunits to the channel itself (Reuveny et al., 1994; Krapivinsky et al., 1995; Herlitze et al., 1996; Ikeda, 1996; De Waard et al., 1997; Zamponi et al., 1997). The attenuation by PKC could therefore involve phosphorylation of the receptor, the G-protein, or the channel. Much work has analyzed attenuation of the modulation of N-type (class B) calcium current by PKC (Golard et al., 1993; Swartz,

\footnotetext{
Received Dec. 8, 1997; revised Jan. 22, 1998; accepted Jan. 22, 1998.

This work was supported by the W. M. Keck Foundation, an Alexander von Humboldt Stiftung Fellowship, Universidad Nacional Autonoma de Mexico DGAPA and Consejo Nacional de Ciencia y Tecnologia, and National Institutes of Health Grants NS01588, DA08934, DA00286, and NS08174. We thank A. Perdichezzi and B. Murphy for help with phosphorylation assays, D. Anderson and L. Miller for technical help, W. Catterall, H. Cruzblanca, J. Isaacson, E. Kaftan, K.T. Kim, D.-S. Koh, J. Roche, and M. Shapiro for reading this manuscript, Y. Lai and A. Nairn for providing protein kinase C, and Sterling Winthrop for providing WIN 55,212-2.

Correspondence should be addressed to Dr. Ken Mackie, University of Washington, Department of Anesthesiology, Box 356540, Seattle, WA 98195-6540.

Copyright (C) 1998 Society for Neuroscience $\quad 0270-6474 / 98 / 182834-08 \$ 05.00 / 0$
}

by phosphorylating CB1 receptors was confirmed by demonstrating that PKC phosphorylated a single serine (S317) of a fusion protein incorporating the third intracellular loop of CB1. Mutating this serine to alanine did not affect the ability of CB1 to modulate currents, but it eliminated disruption by PMA, demonstrating that PKC can disrupt ion channel modulation by receptor phosphorylation.

Key words: cannabinoid; G-protein-coupled receptor; calcium channel; inwardly rectifying potassium channel; protein kinase C; phosphorylation

1993; Zhu and Ikeda, 1994; Shapiro et al., 1996; Zamponi et al., 1997), which is thought to be attributable to phosphorylation of the linker between domains I and II of the $\alpha_{1}$ channel subunit (Zamponi et al., 1997). Much less is known about attenuation of modulation of identified P/Q-type (class A) calcium currents. Results from oocyte experiments raise the possibility that effects of PKC on P/Q-type calcium channels are not mediated by phosphorylation of their $\alpha_{1}$ subunit (Stea et al., 1995). Protein kinase $\mathrm{C}$ can also enhance neuronal excitability by inhibiting potassium current $\mathrm{K}_{\mathrm{ir}}$ currents or their activation (Takano et al., 1995; Velimirovic et al., 1995). One possible explanation for these varied actions of $\mathrm{PKC}$ is that it disrupts a signaling step proximal to ion channels.

Cannabinoids produce their behavioral effects as a consequence of binding to a G-protein-coupled receptor, the CB1 cannabinoid receptor (Matsuda et al., 1990; Pertwee, 1993). The abundance of these receptors and the discovery of several endogenous ligands (Devane et al., 1992; Stella et al., 1997) suggests that cannabinoid neuromodulatory systems play important physiological roles (Di Marzo et al., 1994). Indeed, endogenous cannabinoids are released during chronic painful inflammation and also play a role in some types of memory (Terranova et al., 1996; Richardson et al., 1997). Cellular consequences specifically linked to $\mathrm{CB} 1$ receptor activation include inhibition of adenylyl cyclase and modulation of ion channels (Pertwee, 1993). It is not known whether PKC activation disrupts cannabinoid modulation of ion currents. In this study we used AtT-20 cells, which express P/Qtype calcium current (Mackie et al., 1995), two species of $\mathrm{K}_{\mathrm{ir}}$ channel protein, GIRK1 and GIRK2 (J. Redell, B. L. Tempel, and K. Mackie, unpublished results), and modest N-type calcium currents (Mackie et al., 1995). We compared the effects of PKC activation on modulation of $\mathrm{P} / \mathrm{Q}$-type calcium channels and of $\mathrm{K}_{\mathrm{ir}}$ current in cells stably transfected with rat CB1 cannabinoid receptor and endogenously expressing somatostatin receptors. Activation of protein kinase $\mathrm{C}$ strongly suppressed modulation of 

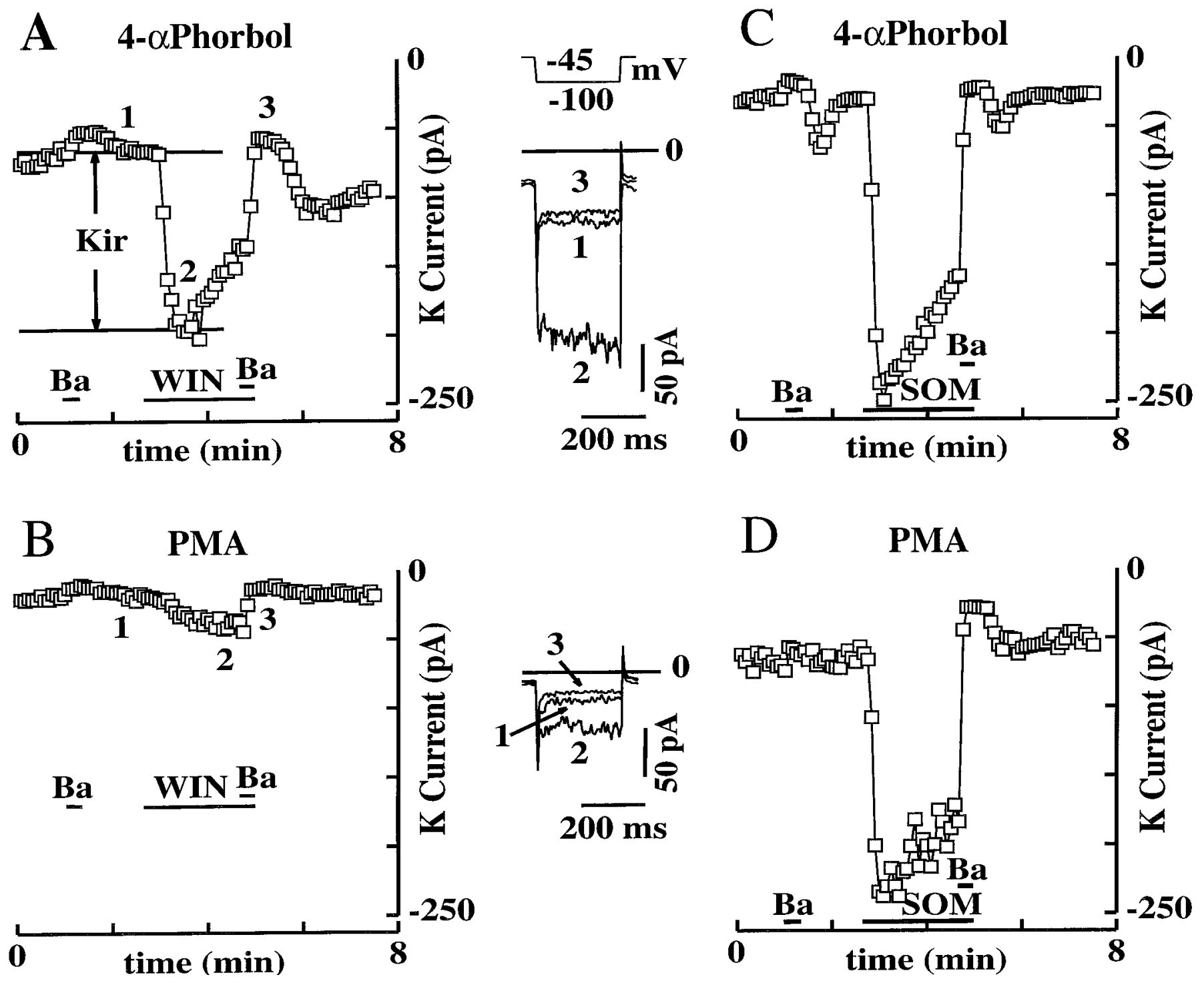

Figure 1. Stimulation of protein kinase $\mathrm{C}$ attenuates activation of $\mathrm{K}_{\mathrm{ir}}$ current by cannabinoids but not by somatostatin. Cells were exposed to 100 nM $4 \alpha$-phorbol or $100 \mathrm{nM}$ PMA for $10 \mathrm{~min}$ at room temperature and transferred to the recording chamber, and potassium currents were recorded. $\mathrm{K}_{\mathrm{ir}}$ current was defined as the component of the current inhibited by $1 \mathrm{mM} \mathrm{Ba}^{2+}$. A, Left, Mean current activated by a 250 msec hyperpolarization to $-100 \mathrm{mV}$ from a holding potential of $-45 \mathrm{mV}$ is plotted versus time in a cell preincubated with $100 \mathrm{~nm} 4 \alpha$-phorbol for 10 min. Bath application of $100 \mathrm{~nm}$ of the cannabimimetic WIN 55,212-2 (WIN) for the indicated time greatly increases the component of the current sensitive to $1 \mathrm{~mm}$ Ba ${ }^{2+}$. The increase in inwardly rectifying potassium current is defined as indicated to the left $\left(\mathrm{K}_{\mathrm{ir}}\right.$ current). Right, Individual current traces taken at the times indicated. B, Left, In a cell pretreated with $100 \mathrm{nM}$ PMA (see Results), $100 \mathrm{nM}$ WIN 55,212-2 slightly increases the barium-sensitive current. Right, Individual current traces taken at the times indicated. $C$, Bath application of $10 \mathrm{~nm}$ somatostatin (SOM) to a cell pretreated with $100 \mathrm{~nm} 4 \alpha$-phorbol for 10 min elicits a large increase in the barium-sensitive inward current. $D$, In a cell pretreated with $100 \mathrm{nM}$ PMA, 10 nM somatostatin still results in a large increase in the barium-sensitive current.

these currents by cannabinoids but only weakly suppressed their modulation by somatostatin. The effect of protein kinase $\mathrm{C}$ appears to be a result of phosphorylation of a serine in the third intracellular loop of CB1.

\section{MATERIALS AND METHODS}

Cell culture. AtT-20 cells stably transfected with rat CB1 (Mackie et al., 1995) or CB1-S317A were plated on poly-L-lysine-coated coverslips and grown in DMEM, 10\% heat-inactivated horse serum, 1:200 penicillin/ streptomycin, and $400 \mu \mathrm{g} / \mathrm{ml} \mathrm{G} 418$ in a humidified environment with $5 \%$ $\mathrm{CO}_{2}$ at $35^{\circ} \mathrm{C}$. Cells were passaged with $0.05 \mathrm{mg} / \mathrm{ml}$ trypsin in PBS and used within 15 passages after the initial clones were isolated.

Electrophysiological recording. Currents were recorded using the wholecell voltage-clamp technique (Hamill et al., 1980). Pipettes were pulled from microhematocrit glass (VWR Scientific) and were fire-polished.
For recording, a coverslip containing cells was transferred to a $200 \mu \mathrm{l}$ chamber that was constantly perfused $(1-2 \mathrm{ml} / \mathrm{min})$ with the appropriate external solution. Solution reservoirs were selected by means of a series of solenoid valves, and solution changes were accomplished in $<30 \mathrm{sec}$. Voltage protocols were generated, and data were digitized, recorded, and analyzed using BASIC-FASTLAB (Indec Systems, Capitola, CA). Liquid junction potentials were uncorrected.

For measuring potassium currents, the pipette solution contained (in $\mathrm{mM}$ ): $120 \mathrm{KCl}, 10 \mathrm{HEPES}, 5$ EGTA, $3 \mathrm{MgCl}_{2}, 3 \mathrm{Na}_{2} \mathrm{ATP}, 0.3 \mathrm{GTP}$, and 0.1 leupeptin, $\mathrm{pH} 7.2$, with $\mathrm{KOH}$, whereas the external solution contained (in $\mathrm{mM}$ ): $40 \mathrm{KCl}, 110 \mathrm{~N}$-methylglucamine, $1 \mathrm{CaCl}_{2}, 25 \mathrm{HEPES}$, and 10 glucose, $\mathrm{pH} 7.35$, with $\mathrm{NaOH}$. Fatty acid-free bovine serum albumin (BSA; $3 \mu \mathrm{M}$ ) was added to decrease adsorption of cannabinoids to surfaces. The $\mathrm{K}_{\mathrm{ir}}$ current was defined as that component of the current sensitive to $1 \mathrm{mM} \mathrm{Ba}^{2+}$ elicited during the final $150 \mathrm{msec}$ of a $250 \mathrm{msec}$ hyperpolarizing pulse to $-100 \mathrm{mV}$ from a holding potential of $-45 \mathrm{mV}$. 


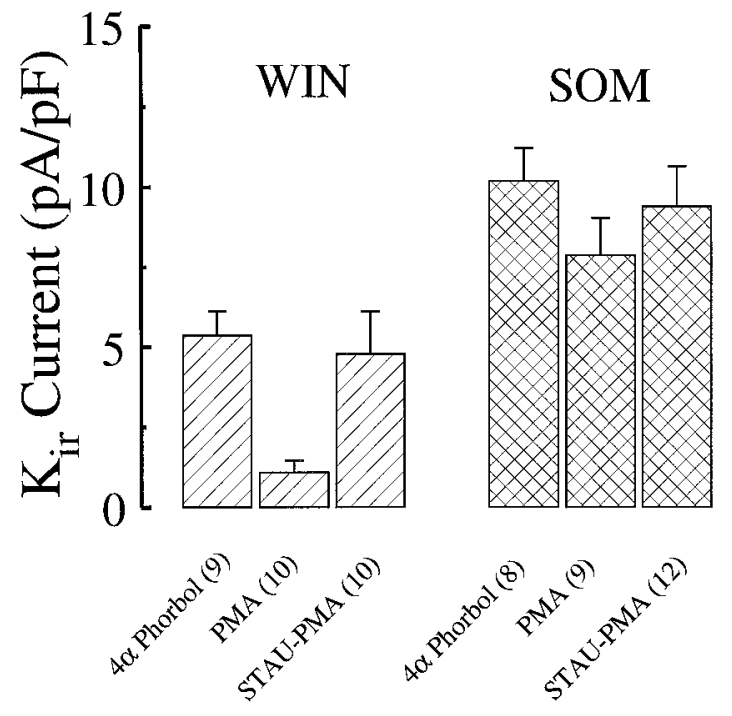

Figure 2. Protein kinase $\mathrm{C}$ stimulation markedly reduces the activation of $\mathrm{K}_{\mathrm{ir}}$ current by cannabinoids but not by somatostatin. Summary of the experiments illustrated in Figure 1 . The $\mathrm{K}_{\mathrm{ir}}$ current activated by $100 \mathrm{~nm}$ WIN 55,212-2 (WIN) and $10 \mathrm{~nm}$ somatostatin (SOM) was normalized to cell capacitance and compared for the following conditions: $100 \mathrm{nM}$ $4 \alpha$-phorbol, $100 \mathrm{~nm}$ PMA (PMA), and $1 \mu \mathrm{M}$ staurosporine (STAU). The number of cells tested for each condition is in parentheses.

Currents were sampled at $1 \mathrm{kHz}$. Because the magnitude of the $\mathrm{K}_{\mathrm{ir}}$ current was dependent on cell size, aggregate current data are presented as current densities normalized to cell capacitance.

For measuring barium currents, the pipette solution contained (in mM): $100 \mathrm{CsCl}, 40$ HEPES, 10 EGTA, $5 \mathrm{MgCl}_{2}$, $3 \mathrm{Na}_{2} \mathrm{ATP}, 0.3 \mathrm{GTP}$, and 0.1 leupeptin, $\mathrm{pH} 7.2$, with $\mathrm{CsOH}$, whereas the external solution contained (in mM): $140 \mathrm{NaCl}, 10 \mathrm{BaCl}_{2}, 5 \mathrm{CsCl}, 1 \mathrm{MgCl}_{2}, 10 \mathrm{HEPES}$, and 10 glucose, $\mathrm{pH} 7.3$, with $\mathrm{NaOH}$. Tetrodotoxin (200 $\mathrm{nM}$ ) was added to block voltage-dependent sodium currents, $2 \mu \mathrm{M}$ nifedipine was added to block L-type calcium currents, and BSA was added to decrease adsorption of the cannabinoids. $I_{\mathrm{Ba}}$ was measured near the end of a $25 \mathrm{msec}$ depolarizing pulse to $0 \mathrm{mV}$ from a holding potential of $-90 \mathrm{mV}$ and was defined as the component of current sensitive to $100 \mu \mathrm{M} \mathrm{CdCl}_{2}$. Currents were sampled at $4 \mathrm{kHz}$.

To control for possible variations of response with passage number and to avoid one source of systematic bias, experimental and control measurements were alternated whenever possible, and concurrent controls were always performed. Where appropriate, data are expressed as mean $\pm \mathrm{SE}$.

Fusion protein generation, purification, and phosphorylation. All fusion proteins were generated in a similar manner using PCR. As an example, the procedure used to generate the IC3 fusion protein follows. An amplicon incorporating the third intracellular loop of the rat $\mathrm{CB} 1$ receptor was generated with the following sense (5'-CGGGATCCTGGAAGGCTCACAGCCAC) and antisense (5'GCGAATTCGGTTTTGGCCAGGCTAAT) primers and digested with EcoRI and BamHI. After ligation into pGEX-3X (Pharmacia, Piscataway, NJ) and transformation, colonies were screened for expression of the appropriate length fusion protein. Mutations were made by direct substitution in the sense primer (S304A) or by the PCR overlap technique (S317A and S323A) (Ho et al., 1989) and were verified by sequencing. Glutathione $S$-transferase (GST) fusion proteins were purified from bacterial lysates using glutathione-Sepharose (Pharmacia).

Phosphorylation of purified GST proteins was performed as described previously, with $50 \mathrm{ng}$ of purified rat brain PKC (a mixture of $\alpha, \beta$, and $\gamma$ isoforms). Phosphorylated proteins were separated on $10 \%$ polyacrylamide gels and identified by autoradiography. Phosphoamino acid analysis was performed using standard techniques (Mackie et al., 1989).

Materials. Tissue culture reagents were from Life Technologies (Gaithersburg, MD); BSA and staurosporine were from Sigma (St. Louis, MO); leupeptin was from Bachem; somatostatin was from Peninsula Labs; and bisindolylmaleimide I (HCl salt), bisindolylmaleimide V, TTX, PMA, $4 \alpha$-phorbol, and GTP were from Calbiochem (La Jolla, CA). WIN 55,212-2 was a gift from Sterling Research Group.

\section{RESULTS}

\section{Stimulation of PKC attenuates cannabinoid activation of $K_{i r}$ current}

Our electrophysiological experiments were designed to examine effects of PKC on receptor-mediated modulation of ion channels. To activate PKC, we exposed cells to a bath solution containing $100 \mathrm{~nm}$ PMA at $20-22^{\circ} \mathrm{C}$ for $10 \mathrm{~min}$. Because the actions of PMA generally do not reverse in tens of minutes, it was not necessary to include PMA in any of the subsequent solutions. Control experiments were done with cells similarly exposed to $100 \mathrm{~nm}$ $4 \alpha$-phorbol, an inactive analog. In both cases, cells were patchclamped within $5 \mathrm{~min}$ of ending the PMA or $4 \alpha$-phorbol incubation.

In cells preincubated with $4 \alpha$-phorbol, $100 \mathrm{~nm}$ WIN 55,212-2 activated $\mathrm{K}_{\mathrm{ir}}$ current in the usual manner in AtT-20 cells stably expressing rat CB1 cannabinoid receptor (Figs. 1A, 2) (cf. Mackie et al., 1995). However, in cells treated with PMA, WIN 55,212-2 activated $\mathrm{K}_{\mathrm{ir}}$ current only minimally (Figs. $1 B, 2$ ). Incubation of the cells for $5 \mathrm{~min}$ with a $1 \mu \mathrm{M}$ concentration of the protein kinase inhibitor staurosporine before incubation with PMA prevented the PMA effect, providing further evidence that PMA was activating a protein kinase (Fig. 2). A briefer stimulation of protein kinase $\mathrm{C}$ by applying phorbol ester for $2.5 \mathrm{~min}$ after establishing the whole-cell recording configuration produced similar but weaker effects. In the cells treated with $4 \alpha$-phorbol, a $100 \mathrm{~nm}$ concentration of the cannabinoid agonist WIN 55,212-2 increased the normalized $\mathrm{K}_{\mathrm{ir}}$ current by $5.2 \pm 0.9 \mathrm{pA} / \mathrm{pF}(n=23)$, whereas in cells treated similarly with PMA, $100 \mathrm{nM}$ WIN $55,212-2$ increased the $\mathrm{K}_{\mathrm{ir}}$ current by only $2.2 \pm 0.5 \mathrm{pA} / \mathrm{pF}$ ( $n=$ 16) (data not shown). PMA applied in this manner had no effect on the $\mathrm{K}_{\mathrm{ir}}$ current before application of WIN 55,212-2 (data not shown).

Somatostatin also activates a $\mathrm{K}_{\mathrm{ir}}$ current in AtT-20 cells (Pennefather et al., 1988). More current is activated in these cells than with cannabinoid or muscarinic agonists, despite the greater density of cannabinoid compared with somatostatin receptors (Felder et al., 1995). This observation suggests that the coupling of endogenous somatostatin receptors to $\mathrm{K}_{\mathrm{ir}}$ current in these cells differs from the coupling of transfected CB1 or endogenous $\mathrm{m}_{4}$ receptors to these channels. Thus it was of interest to investigate the effect of protein kinase $\mathrm{C}$ stimulation on activation of $\mathrm{K}_{\mathrm{ir}}$ current by somatostatin. Surprisingly, preincubation with PMA had little effect on activation of $\mathrm{K}_{\mathrm{ir}}$ current by $10 \mathrm{~nm}$ (Figs. 1D, 2) or by $250 \mathrm{~nm}$ somatostatin $[10.1 \pm 1.6 \mathrm{pA} / \mathrm{pF} ; n=12(4 \alpha-$ phorbol); vs $9.3 \pm 1.4 \mathrm{pA} / \mathrm{pF} ; n=10$ (PMA); data not shown].

\section{Stimulation of PKC attenuates modulation of P/Q-type calcium currents by cannabinoids}

AtT-20 cells also express prominent L-, P/Q-, and R-type highvoltage-activated calcium currents (cf. Mackie et al., 1995). Of these, the P/Q-type current is the major current inhibited by cannabinoids and somatostatin (Mackie et al., 1995). Of note, $\mathrm{N}$-type calcium current, defined as inhibited by $1 \mu \mathrm{M} \omega$-conotoxin GVIA ( $\omega$-CgTX GVIA), is a minor $(<10 \%)$ component of the high-voltage-activated calcium current in these cells (Mackie et al., 1995). Using barium as the charge carrier through calcium channels and nifedipine to block current through L-type calcium channels, we determined whether cannabinoid inhibition of $\mathrm{P} / \mathrm{Q}-$ type calcium channels was blunted by protein kinase $\mathrm{C}$ stimulation. Protein kinase $\mathrm{C}$ was stimulated using the same preincubation protocols as in the $\mathrm{K}_{\mathrm{ir}}$ current experiments. In cells pretreated with $4 \alpha$-phorbol, $100 \mathrm{~nm}$ WIN 55,212-2 inhibited $I_{\mathrm{Ba}}$ 

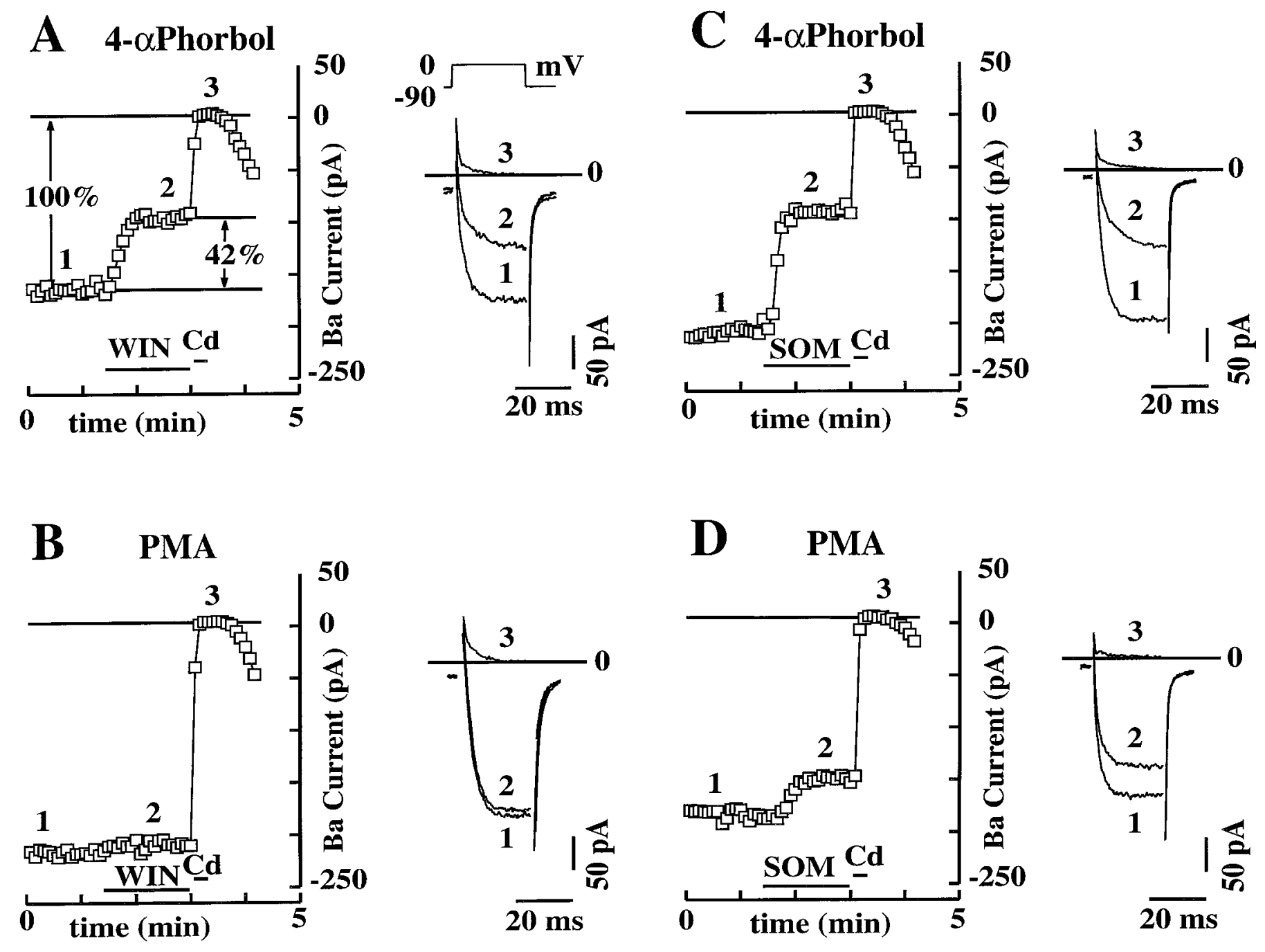

Figure 3. Activation of protein kinase $\mathrm{C}$ greatly reduces inhibition of $\mathrm{P} / \mathrm{Q}$-type calcium currents by cannabinoids but not by somatostatin. Cells were exposed to $100 \mathrm{nM} 4 \alpha$-phorbol or $100 \mathrm{nM}$ PMA for $10 \mathrm{~min}$ at room temperature and transferred to the recording chamber, and barium currents flowing through calcium channels were recorded. $A$, Left, Mean current activated by a $25 \mathrm{msec}$ depolarization to $0 \mathrm{mV}$ from a holding potential of $-80 \mathrm{mV}$ is plotted against time in a cell preincubated for $10 \mathrm{~min}$ with $100 \mathrm{nM} 4 \alpha$-phorbol. Bath application of $100 \mathrm{nM}$ of the cannabimimetic WIN 55,212-2 (WIN) for the indicated time inhibits $\sim 40 \%$ of the barium current [defined as the fraction of the current sensitive to $100 \mu \mathrm{M} \mathrm{CdCl}{ }_{2}(C d)$ ]. Right, Individual current traces taken at the times indicated. B, Left, In a cell pretreated with $100 \mathrm{nM}$ PMA (see text), $100 \mathrm{nM}$ WIN 55,212-2 has a minimal effect on the barium current. Right, Individual current traces taken at the times indicated. $C$, Bath application of $10 \mathrm{~nm}$ somatostatin (SOM) to a cell pretreated with $100 \mathrm{~nm} 4 \alpha$-phorbol for $10 \mathrm{~min}$ inhibits $\sim 50 \%$ of the barium current. $D$, In a cell pretreated with $100 \mathrm{~nm}$ PMA, $10 \mathrm{~nm}$ somatostatin still inhibits a significant fraction of the barium current.

(Figs. 3A, 4), as expected from previous studies (Mackie et al., 1995). However, pretreatment with PMA markedly attenuated the inhibition by WIN 55,212-2 (Figs. 3B, 4). Further evidence that the attenuation was mediated by protein kinase $\mathrm{C}$ included the findings that it was prevented by previous treatment with $1 \mu \mathrm{M}$ staurosporine or a $100 \mathrm{~nm}$ concentration of the more specific protein kinase $\mathrm{C}$ inhibitor bisindolylmaleimide I (Fig. 4). The inactive analog bisindolylmaleimide $\mathrm{V}$ did not inhibit the PMA effect (Fig. 4).

We repeated the same protocols with somatostatin as the agonist. Protein kinase $\mathrm{C}$ activation decreased inhibition of the barium current by somatostatin less effectively than it decreased inhibition by cannabinoid (Fig. 4). Preincubation with PMA reduced barium current inhibition by $10 \mathrm{~nm}$ somatostatin from $45 \pm$ $3 \%(n=18)$ to $28 \pm 3 \%(n=17)(p<0.0005)$ (Figs. $3 D, 4)$. Because N-type calcium current comprises only $10 \%$ of the high- voltage-activated calcium current, it is likely that the reduction in modulation by PMA reflects decreased inhibition of both $\mathrm{P} / \mathrm{Q}$ and N-type calcium channels. Again, further evidence for involvement of PKC comes from the observation that $1 \mu \mathrm{M}$ staurosporine and $100 \mathrm{~nm}$ bisindolylmaleimide I prevented the PMA effect, whereas bisindolylmaleimide V was ineffective (Fig. 4).

\section{Protein kinase $\mathbf{C}$ phosphorylates a fusion protein containing the third intracellular loop of the CB1 receptor}

Because attenuation by $\mathrm{PKC}$ was much greater for cannabinoidmediated actions than for somatostatin-mediated ones, we reasoned that CB1 receptors might be directly phosphorylated by PKC. We undertook a biochemical approach to test this possibility by constructing glutathione $S$-transferase fusion proteins for each of the intracellular domains of the rat $\mathrm{CB} 1$ receptor. The 


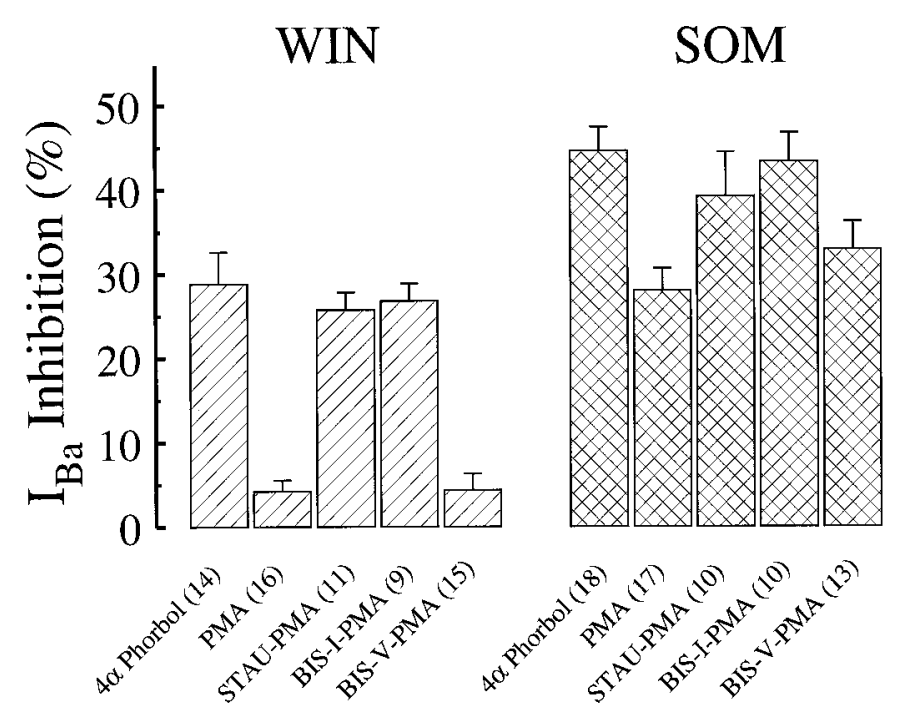

Figure 4. Protein kinase C stimulation greatly reduces the inhibition of barium current by cannabinoids but not by somatostatin. Summary of the experiments illustrated in Figure 3. The barium current activated by 100 nM WIN 55,212-2 (WIN) and $10 \mathrm{~nm}$ somatostatin (SOM) was compared for the following conditions: $100 \mathrm{nM} 4 \alpha$-phorbol, $100 \mathrm{nM}$ PMA (PMA), 1 $\mu \mathrm{M}$ staurosporine $(S T A U), 100 \mathrm{~nm}$ bisindolylmaleimide I $(B I S)$, and 100 $\mathrm{nm}$ bisindolylmaleimide $\mathrm{V}(I B I S)$. The number of cells tested for each condition is indicated in parentheses.

fusion proteins for intracellular loops I and III (IC3) could be phosphorylated by purified protein kinase $\mathrm{C}$, whereas fusion proteins for the second intracellular loop and $\mathrm{C}$ terminus could not (data not shown). Because the third intracellular loop is important for signaling in many G-protein-coupled receptors, further efforts focused on this loop. Phosphoamino acid analysis demonstrated that the IC3 fusion protein was phosphorylated on serine (data not shown). IC3 contains three serines, so three fusion proteins were constructed; in each a different serine was mutated to alanine (S304A, S317A, S323A). Whereas the mutant S317A protein was a poor substrate for PKC, the S304A and S323A proteins were phosphorylated as effectively as the wildtype IC3 fusion protein (Fig. 5). The low amounts of phosphorylation seen in the S317A mutant suggest that PKC can phosphorylate at least one of the two other serines in IC3, but to a lesser degree. These results suggested that S317 is the best PKC site in the third intracellular loop and that its phosphorylation might be responsible for the $\mathrm{PKC}$-mediated disruption of $\mathrm{CB} 1$ signaling seen in the electrophysiological experiments. To test this possibility, we mutated S317 to alanine in the full-length rat CB1 and stably expressed it in AtT-20 cells.

\section{Mutation of serine 317 in rat CB1 abolishes PKC- mediated disruption of CB1 signaling}

We first tested the coupling of CB1-S317A to $\mathrm{K}_{\mathrm{ir}}$ current. Figure 6, $A$ and $C$, shows that WIN 55,212-2 could activate $\mathrm{K}_{\mathrm{ir}}$ current in AtT-20 cells expressing the CB1-S317A mutant as effectively as in cells expressing wild-type CB1 $(6.3 \pm 0.4 \mathrm{pA} / \mathrm{pF} ; n=6$; vs $6.7 \pm$ $0.7 \mathrm{pA} / \mathrm{pF} ; n=5)$. Furthermore, whereas preincubation with 100 nM PMA strongly reduced $\mathrm{K}_{\mathrm{ir}}$ current activation by WIN 55,212-2 in cells expressing the wild-type CB1 receptor, it had no effect on cells expressing CB1-S317A $(1.7 \pm 0.2 \mathrm{pA} / \mathrm{pF} ; n=8$; vs $6.3 \pm 0.4 \mathrm{pA} / \mathrm{pF} ; n=10$ ) (Fig. $6 B, C$ ). Thus PKC appears to disrupt activation of $\mathrm{K}_{\mathrm{ir}}$ current by the $\mathrm{CB} 1$ receptor by phosphorylating the receptor on serine 317 .

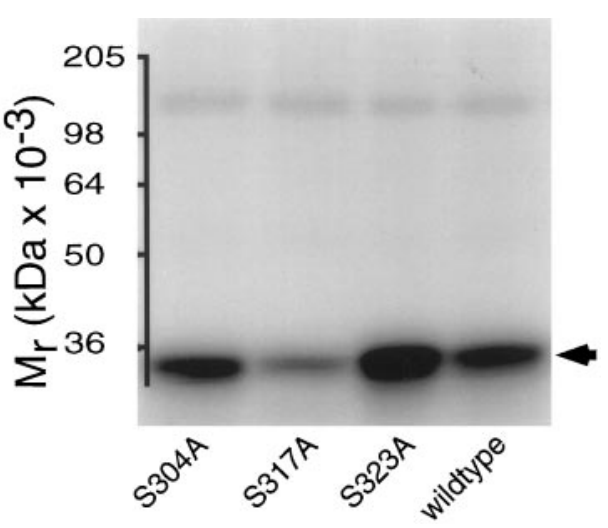

Figure 5. Protein kinase C phosphorylates GST-IC3 fusion proteins on the serine corresponding to serine 317 in rat CB1. Fusion proteins were phosphorylated by purified rat brain PKC (50 ng) for $30 \mathrm{~min}$ and separated by SDS-PAGE. Phosphorylated proteins were identified by autoradiography of the gel. Wild-type third intracellular loop, S304A, and S323A fusion proteins were phosphorylated to a similar extent, whereas the S317A fusion protein was minimally phosphorylated. Arrowhead, GST-IC3 fusion protein.

We next tested the coupling of CB1-S317A to calcium channels. Figure 7, $A$ and $C$, shows that cannabinoid agonist inhibited calcium channels in AtT-20 cells expressing the CB1-S317A mutant to the same extent as in cells expressing wild-type CB1 $(30.8 \pm 1.5 \% ; n=5 ;$ vs $31.1 \pm 1.1 \% ; n=5)$. However, whereas preincubation with $100 \mathrm{nM}$ PMA strongly reduced inhibition of the calcium channels by WIN 55,212-2 in cells expressing wildtype CB1, the same treatment had a much smaller effect on cells expressing CB1-S317A $(7.2 \pm 3.6 \% ; n=7$; vs $24.6 \pm 2.3 \%$; $n=$ 11) (Fig. $7 B, C)$. Evidently PKC strongly disrupts the inhibition of calcium channels by the $\mathrm{CB} 1$ receptor when it phosphorylates the CB1 receptor on serine 317.

Although most of the attenuation of CB1 inhibition of total barium current was prevented by the S317A mutation, a small effect of PMA remained (Fig. 7C). We hypothesized that this might reflect $\mathrm{CB} 1$ modulation of the small number of N-type calcium channels present in these cells (Mackie et al., 1995). PKC attenuation of this kind of modulation is likely to be a consequence of phosphorylation of the $\alpha_{1 \mathrm{~B}}$ channel subunit and thus would not be rescued by mutation of the CB1 receptor. To test this possibility we blocked the N-type current by $1 \mu \mathrm{M} \omega$-CgTX GVIA. Figure $7 C$ shows that in the $\omega$-CgTX GVIA-treated CB1-S317A cells, WIN inhibited the barium current to a similar extent in the $4 \alpha$-phorbol- and PMA-treated cells. These results suggest that the modest reduction by PMA of barium current inhibition by cannabinoids in the S317A mutant is attributable to action on N-type calcium channels, consistent with the hypothesis that by phosphorylating the linker between domains I and II of $\alpha_{1 \text { в }}$ (Stea et al., 1995; Zamponi et al., 1997), PKC weakens $\mathrm{G}$-protein $\beta \gamma$ subunit binding to the channel.

\section{DISCUSSION}

We have discovered a potent physiological consequence of phosphorylating cannabinoid receptors by protein kinase C. Modulation of $\mathrm{K}_{\mathrm{ir}}$ current and $\mathrm{P} / \mathrm{Q}$-type calcium channels by cannabinoids is exquisitely sensitive to inhibition by protein kinase $\mathrm{C}$, and the inhibition is largely attributable to the phosphorylation of the CB1 receptor on a single serine in the third intracellular loop.

This sensitivity provides a mechanism for neuromodulators that activate protein kinase $\mathrm{C}$ (such as substance $\mathrm{P}$ or glutamate 

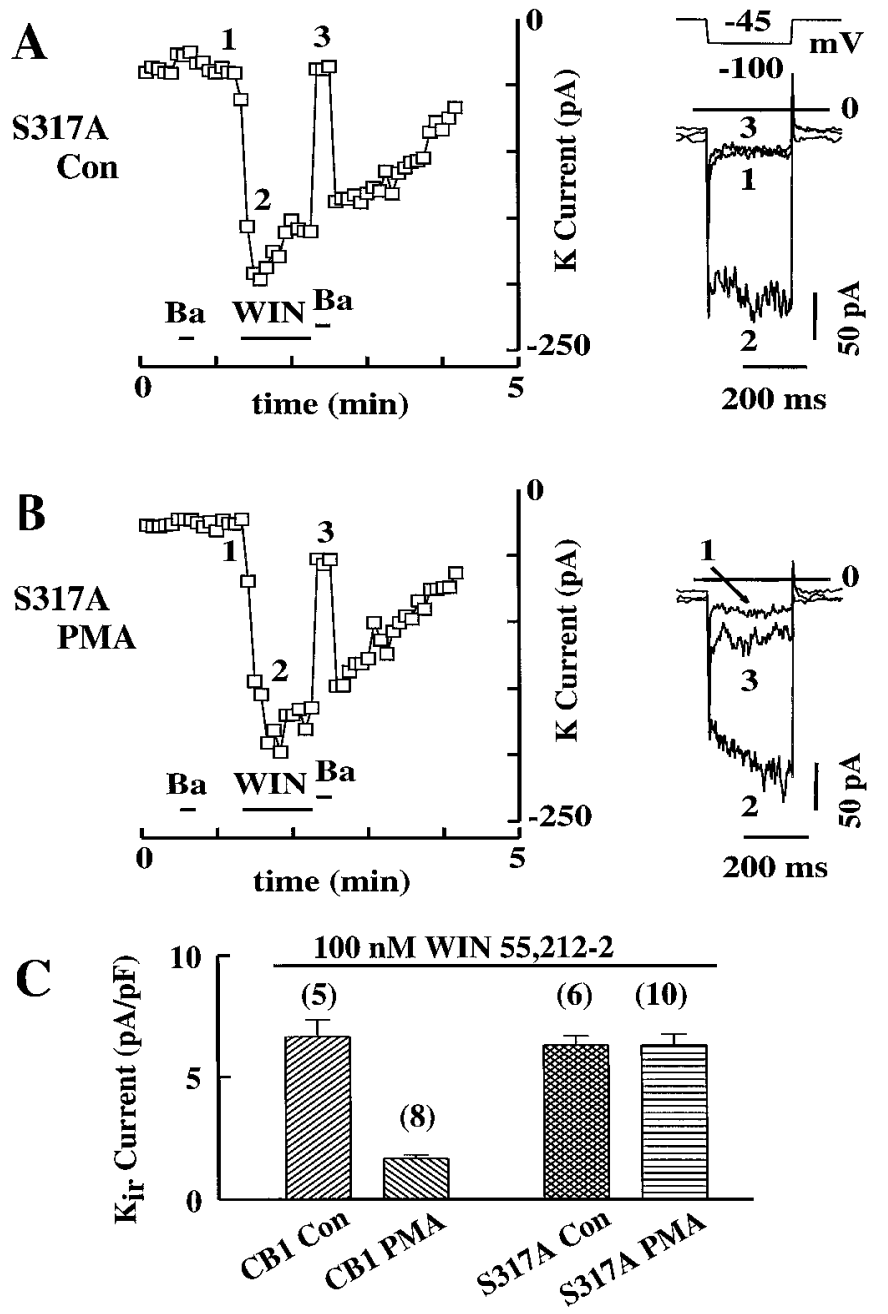

Figure 6. The CB1-S317A mutant receptor activation of $\mathrm{K}_{\mathrm{ir}}$ current is not attenuated by protein kinase C. $A$, Time course of $\mathrm{K}_{\mathrm{ir}}$ current activation by $100 \mathrm{nM}$ WIN 55,212-2 in a CB1-S317A cell after preincubation with $100 \mathrm{~nm} 4 \alpha$-phorbol (Con). Inset, Current traces from the indicated times. $B$, Time course of $\mathrm{K}_{\mathrm{ir}}$ current activation by $100 \mathrm{~nm}$ WIN 55,212-2 after preincubation with $100 \mathrm{nM}$ PMA to stimulate protein kinase C. Inset, Current traces from the indicated times. $C$, Comparison of $\mathrm{K}_{\mathrm{ir}}$ current activation in cells expressing CB1 or CB1-S317A. The number of cells for each condition is in parentheses.

acting at metabotropic glutamate receptors) to attenuate the effects of cannabinoids on neuronal excitability. The CB1 receptor mediates inhibition of adenylyl cyclase (Howlett, 1985) and calcium currents (Mackie and Hille, 1992; Mackie et al., 1995) and activation of potassium currents (Henry and Chavkin, 1995; Mackie et al., 1995). Because most of these actions tend to decrease the excitability of a neuron and synaptic transmission, stimulation of PKC provides a mechanism whereby neurotransmitters coupled with protein kinase $\mathrm{C}$ can restore neuronal excitability and synaptic strength when endogenous cannabinoid levels are high. Whereas the CB1 receptor was the subject of these studies, our results probably apply to other G-protein-coupled receptors. It will be interesting to learn how widespread this kind of crosstalk is.

It is well established that modulation of $\mathrm{N}$ - and P/Q-type calcium channels by G-protein-coupled receptors can be disrupted by activation of protein kinase C (Golard et al., 1993; Swartz, 1993; Zhu and Ikeda, 1994; Stea et al., 1995; Shapiro et
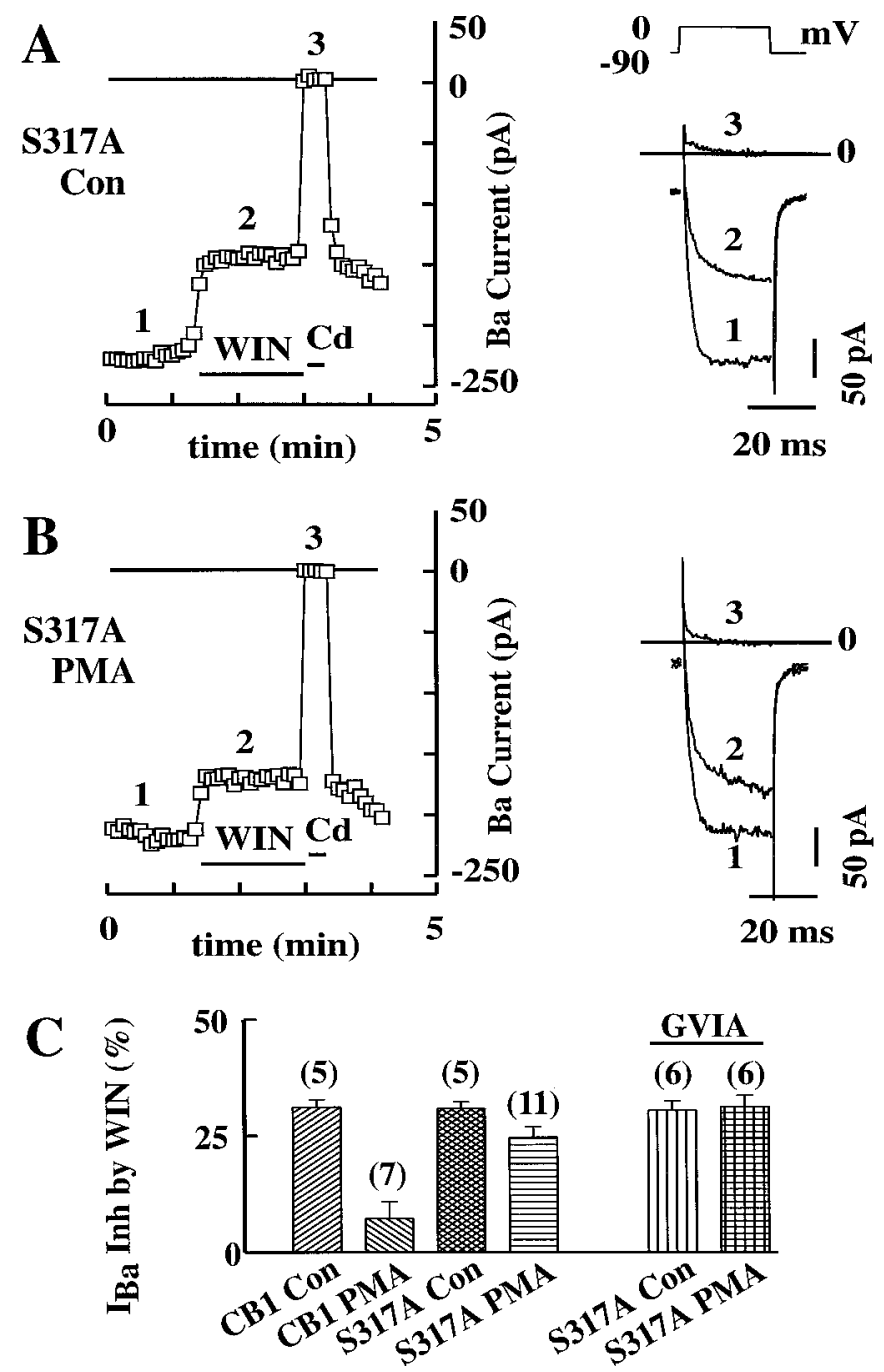

Figure 7. The CB1-S317A mutant receptor inhibition of calcium channels is resistant to PKC. $A$, Time course of barium current inhibition by $100 \mathrm{~nm}$ WIN 55,212-2 in a CB1-S317A cell after preincubation with 100 nм $4 \alpha$-phorbol (Con). Inset, Current traces from the indicated times. $B$, Time course of barium current inhibition by $100 \mathrm{~nm}$ WIN 55,212-2 after preincubation with $100 \mathrm{nM}$ PMA to stimulate protein kinase C. Inset, Current traces from the indicated times. $C$, Comparison of barium current inhibition (Inh) in cells expressing CB1 or CB1-S317A. The small residual PMA effect in the S317A mutant was abolished by $\omega$-conotoxin GVIA (GVIA). The number of cells for each condition is in parentheses.

al., 1996). For $\alpha_{1 \text { в }}$ (N-type) calcium channels, the suppression has been attributed to direct phosphorylation of the channel. PKC phosphorylates the domain I-II linker of the $\alpha_{1 \mathrm{~B}}$ subunit at a site (or sites) possibly involved in binding of G-protein $\beta \gamma$ subunits (Stea et al., 1995; Zamponi et al., 1997). This covalent modification of the target channel would be expected to suppress actions of free G- $\beta \gamma$ subunits regardless of which agonist and receptor had generated them. However, with P/Q-type channels, we have found that the effects of cannabinoids are very sensitive to PKC activation, whereas those of somatostatin are affected slightly. [Because N-type current is only a minor $(<10 \%)$ component of the calcium current in these cells, and somatostatin inhibits $>40 \%$ of the calcium current, most of the current that somatostatin inhibits must be $\mathrm{P} / \mathrm{Q}$ type.] The receptor-specific nature of actions on $\mathrm{P} / \mathrm{Q}$ current modulation suggests that activation of 
PKC does not materially reduce the sensitivity of $\mathrm{P} / \mathrm{Q}$ channels to $\mathrm{G}-\beta \gamma$ subunits. This conclusion is in accord with earlier findings that PKC activation does not change the amplitude of currents from expressed $\alpha_{1 \mathrm{~A}}$ subunits, whereas it does change the amplitudes of those from $\alpha_{1 \mathrm{~B}}$ subunits (Stea et al., 1995; Zamponi et al., 1997). When interpreting our results, it must be kept in mind that there are alternatively spliced forms of $\alpha_{1 \mathrm{~A}}$ (e.g., Sakurai et al., 1995) and that these may be affected differently from the form(s) expressed in AtT-20 cells. The insensitivity of $\mathrm{P} / \mathrm{Q}$ channels in these cells to a direct action of PKC makes them an effector of choice in future studies to characterize receptor-specific actions of PKC.

Our results also provide insight into the role PKC has in inhibiting activation of $\mathrm{K}_{\mathrm{ir}}$ currents. They are the first demonstration that phosphorylation of a G-protein-coupled receptor can disrupt its activation of a $\mathrm{K}_{\mathrm{ir}}$ current. In some studies, activation of $\mathrm{K}_{\mathrm{ir}}$ currents by G-protein-coupled receptors is found to be disrupted by PKC stimulation, whereas in others it is not. In a nice series of studies in cultured nucleus basalis and locus coeruleus neurons, Yamaguchi et al. (1990), Farkas et al. (1994), and Velimirovic et al. (1995) found that $\mathrm{K}_{\mathrm{ir}}$ currents are inhibited by substance $\mathrm{P}$ and neurotensin. In locus coeruleus neurons, in which a $\mathrm{K}_{\mathrm{ir}}$ current is activated by somatostatin and Met-enkephalin, activation is prevented by substance P. Whereas the molecular identity of these currents has not been identified (Takano et al., 1996), the actions of substance $P$ (and probably neurotensin) in nucleus basalis neurons are mediated by protein kinase $\mathrm{C}$ (Takano et al., 1995). In contrast, activation of $\mathrm{K}_{\mathrm{ir}}$ current in acutely isolated dorsal raphe neurons by the $5-\mathrm{HT}_{1 \mathrm{~A}}$ receptor is not sensitive to stimulation of PKC (Chen and Penington, 1996), demonstrating heterogeneity in the interaction of $\mathrm{PKC}$ with $\mathrm{K}_{\mathrm{ir}}$ current activation. In AtT-20 cells we have also found receptorspecific effects; CB1-mediated activation of $\mathrm{K}_{\mathrm{ir}}$ current was sensitive to PKC stimulation, whereas somatostatin activation was not. AtT-20 cells express mRNA for at least five subtypes of somatostatin receptor (Kaupman et al., 1993). Presumably the G-protein-coupled signaling of at least one of the somatostatin receptors expressed in AtT-20 cells is not interrupted by PKC. By RT-PCR, AtT-20 cells express GIRK1 and GIRK2 but not GIRK3 or GIRK4 (CIR) (J. Redell, B. L. Tempel, and K. Mackie, unpublished results). GIRK1 and GIRK2 have multiple consensus sequences for PKC phosphorylation. Nevertheless, activation of $\mathrm{K}_{\mathrm{ir}}$ currents by cannabinoids in cells expressing the S317A-CB1 receptor and activation by somatostatin were unaffected by stimulation of PKC. Thus any phosphorylation by PKC of these GIRK proteins does not perturb their activation by the G- $\beta \gamma$ subunits liberated after CB1 receptor stimulation.

In summary, cannabinoid modulation of P/Q- and N-type calcium and $\mathrm{K}_{\mathrm{ir}}$ channels is exquisitely sensitive to disruption by protein kinase $\mathrm{C}$ stimulation. Based on our results, one might even imagine that activation of phospholipase $\mathrm{C}$-linked receptors could be viewed as a potential "antidote" to psychoactive effects of marijuana. Disruption of CB1-mediated P/Q-type calcium channel inhibition and $\mathrm{K}_{\mathrm{ir}}$ current activation by PKC is chiefly a consequence of phosphorylation of the third intracellular loop of the CB1 receptor. This is the first demonstration that the phosphorylation of a G-protein-coupled receptor by protein kinase $\mathrm{C}$ can disrupt the modulation of ion channels by the receptor. The high sensitivity of the response provides a point of potential crosstalk and integration of diverse signals, such as that between endogenous cannabinoids and neuromodulators that activate phospholipase C-linked receptors. It seems quite likely that mod- ulation of channels by certain other G-protein-coupled receptors will be attenuated by PKC via a similar mechanism.

\section{REFERENCES}

Capogna M, Gahwiler BH, Thompson SM (1995) Presynaptic enhancement of inhibitory synaptic transmission by protein kinases $\mathrm{A}$ and $\mathrm{C}$ in the rat hippocampus in vivo. J Neurosci 15:1249-1260.

Chen Y, Penington NJ (1996) Differential effects of protein kinase C activation on $5-\mathrm{HT}_{1 \mathrm{~A}}$ receptor coupling to $\mathrm{Ca}^{2+}$ and $\mathrm{K}^{+}$currents in rat serotonergic neurons. J Physiol (Lond) 496:129-137.

De Waard M, Liu H, Walker D, Scott VES, Gurnett CA, Campbell KP (1997) Direct binding of G-protein $\beta \gamma$ complex to voltage-dependent calcium channels. Nature 385:446-450.

Devane WA, Hanus L, Breuer A, Pertwee RG, Stevenson LA, Griffin G, Givson D, Mandelbaum A, Etinger A, Mechoulam R (1992) Isolation and structure of a brain constituent that binds to the cannabinoid receptor. Science 258:1946-1949.

Di Marzo V, Fontana A, Cadas H, Schinelli S, Cimino G, Schwartz J-C, Piomelli D (1994) Formation and inactivation of endogenous cannabinoids in central neurons. Nature 372:686-691.

Farkas RH, Nakajima S, Nakajima Y (1994) Neurotensin excites basal forebrain cholinergic neurons: ionic and signal-transduction mechanisms. Proc Natl Acad Sci USA 91:2853-2857.

Felder CC, Joyce KE, Briley EM, Mansouri J, Mackie KM, Blond O, Lai Y, Ma AL, Mitchell RL (1995) Comparison of the pharmacology and signal transduction of the human cannabinoid $\mathrm{CB} 1$ and $\mathrm{CB} 2$ receptors. Mol Pharmacol 48:443-450.

Golard A, Role LW, Siegelbaum SA (1993) Protein kinase C blocks somatostatin-induced modulation of calcium current in chick sympathetic neurons. J Neurophysiol 70:1639-1643.

Hamill OP, Marty A, Neher E, Sakmann B, Sigworth FJ (1980) Improved patch-clamp techniques for high-resolution current recording from cell and cell-free membrane patches. Pflugers Arch 391:85-100.

Henry DC, Chavkin C (1995) Activation of inwardly rectifying potassium channels (GIRK1) by co-expressed rat brain cannabinoid receptor in Xenopus oocytes. Neurosci Lett 186:91-94.

Herlitze S, Garcia DE, Mackie K, Hille B, Scheuer T, Catterall WA (1996) Modulation of $\mathrm{Ca}^{2+}$ channels by G-protein $\beta \gamma$ subunits. Nature 380:258-262.

Hille B (1994) Modulation of ion-channel function by G-protein-coupled receptors. Trends Neurosci 17:531-536.

Ho SN, Hunt HD, Horton RM, Pullen JK, Pease LR (1989) Sitedirected mutagenesis by overlap extension using the polymerase chain reaction. Gene 77:51-59.

Howlett AC (1985) Cannabinoid inhibition of adenylate cyclase: biochemistry of the response in neuroblastoma cell membranes. Mol Pharmacol 27:429-436.

Huang KP, Huang FL (1993) How is protein kinase C activated in CNS? Neurochem Int 22:417-33.

Ikeda SR (1996) Voltage-dependent modulation of N-type calcium channels by G-protein $\beta \gamma$ subunits. Nature 380:255-258.

Kaupman K, Bruns C, Hoyer P, Seuwen K, Lubbert H (1993) Distribution and second messenger coupling of four somatostatin receptor subtypes expressed in brain. FEBS Lett 331:53-59.

Krapivinsky G, Gordon EA, Wickman K, Velimirovic B, Krapivinsky L, Clapham DE (1995) The G-protein-gated atrial $\mathrm{K}^{+}$channel $\mathrm{I}_{\mathrm{KACh}}$ is a heteromultimer of two inwardly rectifying potassium channels. Nature 374:135-141.

Mackie K, Hille B (1992) Cannabinoids inhibit N-type calcium current in neuroblastoma-glioma cells. Proc Natl Acad Sci USA 89:3825-3829.

Mackie K, Sorkin BC, Nairn AC, Greengard P, Edelman GM, Cunningham BA (1989) Identification of two protein kinases that phosphorylate the neural cell-adhesion molecule, N-CAM. J Neurosci 9:1883-1896.

Mackie K, Lai Y, Westenbroek R, Mitchell R (1995) Cannabinoids activate an inwardly-rectifying potassium conductance and inhibit Q-type voltage-dependent calcium currents in AtT-20 cells transfected with rat brain cannabinoid receptor. J Neurosci 15:6552-6561.

Malenka RC, Madison DV, Nicoll RA (1986) Potentiation of synaptic transmission in hippocampus by phorbol esters. Nature 321:175-177.

Matsuda LA, Lolait SJ, Brownstein MJ, Young AC, Bonner TI (1990) Structure of a cannabinoid receptor and functional expression of the cloned cDNA. Nature 346:561-564.

North RA (1989) Drug receptors and the inhibition of nerve cells. Br J Pharmacol 98:13-28. 
Pennefather PS, Heisler S, MacDonald JF (1988) A potassium conductance contributes to the action of somatostatin-14 to suppress ACTH secretion. Brain Res 444:436-450.

Pertwee RG (1993) Evidence for the existence of cannabinoid receptors. Gen Pharmacol 24:811-824.

Reuveny E, Slesinger PA, Inglese J, Morales JM, Inlguez-Lluhl JA, Lefkowitz RJ, Bourne HR, Jan YN, Jan LY (1994) Activation of the cloned muscarinic potassium channel by G-protein $\beta \gamma$ subunits. Nature 370:143-146.

Richardson JD, Aanonsen L, Hargreaves KM (1997) SR 141716A, a cannabinoid receptor antagonist, produces hyperalgesia in untreated mice. Eur J Pharmacol 319:2-3.

Sakurai T, Hell JW, Woppmann A, Miljanich GP, Catterall WA (1995) Immunochemical identification and differential phosphorylation of alternatively spliced forms of the $\alpha_{1 \mathrm{~A}}$ subunit of brain calcium channels. J Biol Chem 270:21234-21242.

Shapiro MS, Zhou J, Hille B (1996) Selective disruption by protein kinase $\mathrm{C}$ of G-protein-mediated $\mathrm{Ca}^{2+}$ channel modulation. J Neurophysiol 76:311-320.

Stea A, Soong TW, Snutch TP (1995) Determinants of PKC-dependent modulation of a family of neuronal calcium channels. Neuron 15:929-940.

Stella N, Schweitzer P, Piomelli D (1997) A second endogenous cannabinoid that modulates long-term potentiation. Nature 388:773-778.

Swartz KJ (1993) Modulation of $\mathrm{Ca}^{2+}$ channels by protein kinase $\mathrm{C}$ in rat central and peripheral neurons: disruption of G-protein-mediated inhibition. Neuron 11:305-320.

Takano K, Stanfield PR, Nakajima S, Nakajima Y (1995) Protein kinase $\mathrm{C}$-mediated inhibition of an inward rectifier potassium channel by substance $P$ in nucleus basalis neurons. Neuron 14:999-1008.

Takano K, Yasufuku-Takano J, Kozasa T, Singer WD, Nakajima S, Nakajima $Y$ (1996) $G_{q / 11}$ and PLC- $\beta 1$ mediate the substance P-induced inhibition of an inward rectifier $\mathrm{K}^{+}$channel in brain neurons. J Neurophysiol 76:2131-2136.

Terranova JP, Storme JJ, Lafon N, P'e'rio A, Rinaldi-Carmona M, Le-Fur G, Soubri'e P (1996) Improvement of memory in rodents by the selective CB1 cannabinoid receptor antagonist, SR141716. Psychopharmacology 126:165-172.

Velimirovic BM, Koyano K, Nakajima S, Nakajima Y (1995) Opposing mechanisms of regulation of $\mathrm{G}$-protein-coupled inward rectifier $\mathrm{K}^{+}$ channel in rat brain neurons. Proc Natl Acad Sci USA 92:1590-1594.

Yamaguchi K, Nakajima Y, Nakajima S, Stanfield PR (1990) Modulation of inwardly rectifying channels by substance $\mathrm{P}$ in cholinergic neurones from rat brain in culture. J Physiol (Lond) 426:499-520.

Zamponi GW, Bourinett E, Nelson D, Nargeot J, Snutch TP (1997) Crosstalk between G-proteins and protein kinase $\mathrm{C}$ mediated by the calcium channel $\alpha_{1}$ subunit. Nature 385:442-446.

Zhu Y, Ikeda SR (1994) Modulation of $\mathrm{Ca}^{2+}$ currents by protein kinase $\mathrm{C}$ in adult rat sympathetic neurons. J Neurophysiol 72:15491560 . 